\title{
A Rare Case of Non-cerebral Coenurus Cyst on the Heart of a Ewe
}

\author{
Nadir Bir Olgu Olarak Koyun Kalbinde Saptanan Non-serebral Coenurus \\ Kisti
}

(1) Vahid Noaman

Isfahan Agricultural and Natural Resources Research and Education Center, AREEO, Isfahan, Iran Veterinary Group, Animal Science Research Department, Isfahan, Iran

\author{
Cite this article as: Noaman V. A Rare Case of Non-cerebral Coenurus Cyst on the Heart of a Ewe. Turkiye Parazitol Derg \\ 2019;43(2):92-5.
}

\begin{abstract}
During the routine postmortem inspection from carcasses and offal of slaughtered ewes in an abattoir in Isfahan (Iran), an ovine heart was discovered with a firm nodule in the myocard on palpation. In closer examination, a liquid containing cyst $(1 \mathrm{x} 1 \mathrm{~cm})$ was recognized on left part of the heart. The cyst had thick fibrotic capsule in outer surface and a thin inner layer containing few white clusters of scolices. White clusters contained scolices that adhered to the inner transparent layer, like white beads. Based on the gross and microscopical characteristics, the cyst was diagnosed as non-cerebral coenurus cyst. This is a rare report of heart coenurosis in a sheep.
\end{abstract}

Keywords: Non-cerebral, coenurus cyst, heart, ewe

ÖZ

İsfahan'da (İran) bir mezbahada kesilen koyunların parçalarında ve sakatatlarında yapılan rutin ölüm sonrası muayene sırasında, palpasyon ile miyokardında bir nodül saptanan bir koyun kalbi keşfedildi. Daha ayrıntılı incelendiğinde, kalbin sol kısmında 1x1 cm boyutlarında içi sıvı dolu bir kist olduğu görüldü. Kistin dış yüzeyinde kalın fibrotik kapsül vardı ve kistin birkaç beyaz skoleks kümesi içeren ince bir iç tabakası vardı. Beyaz kümeler, beyaz boncuklar gibi iç şeffaf tabakaya yapışan skoleksler içeriyordu. Kistin makroskopik ve mikroskopik özelliklerine dayanarak, non-serebral coenurus kisti olduğu teşhis edildi. Bu, koyun kalp coenurosisinin nadir bir örneğidir.

Anahtar Kelimeler: Non-serebral, coenurus kisti, kalp, koyun

\section{INTRODUCTION}

Coenurosis is an important zoonotic disease that causes serious economic losses in small ruminants and severe disease in human $(1,2)$. Infection is common in worldwide especially in the Middle East countries where the small ruminants are the most resource of meat and milk (1).

Coenurus cysts are the metacestode of Taenia (multiceps) species and specially affect herbivores such as sheep and goats. In appearance, the cysts are generally round and have a semitransparent outer wall with several protoscoleces connected to the inner layer. The scolex same as typical taeniid has a double row of hooks. On average, there is 85 scoleces in each coenurus cyst. The highest and lowest number of scoleces in each cyst is 40 and 550, respectively (3). The diameter of the cysts is between 0.8 and 6.5 $\mathrm{cm}$ and is full of fluid. Furthermore, cysts contain several scolices that are easily visible. In microscopic examination the scolices have a rostellum with two rows hooks and four suckers (4).

Coenurus cerebralis or metacestode of Multiceps causes cerebral coenurosis in sheep and goats (5). Benkovskij (1899) (4) and Gaiger (1907) (6) for the first time reported the non-cerebral coenurosis in sheep and goat, respectively $(6,7)$.

The causative agents of the non-cerebral cysts were originally called as Multiceps gaigeri in goats and Multiceps skrjabini in sheep by Hall (1916) (7) and Popov (1937) respectively $(8,9)$. 
Verster (1969) revised the genus Taenia; he considered Taenia multiceps (T.multiceps) as alternative word of Taenia skrjabini (T. skrjabini) and Taenia gaigeri (T. gaigeri) (10). In recent studies based on Verster's views, T. skrjabini was neglected and T. multiceps was chosen instead of T. gaigeri (11).

Molecular studies on non-cerebral cysts in goats reinforced the viewpoint that $T$. gaigeri was a synonym of $T$. multiceps, and intraspecific sequence variation was only significant difference between strains of T. multiceps $(1,12)$. A study in a geographical region of Iran showed that protoscolices of coenurus cysts collected from both the brains of sheep and the muscles of goats produced the similar adult worms in dog intestine (13). This result confirmed former Iranian researcher's opinion that cerebral coenurosis could also affect the other tissues to produce noncerebral coenurosis (14). Furthermore, molecular study based on two mitochondrial (cox1 and nad1) markers and an exonic region of the enolase (ENO) gene confirmed that both cerebral cysts from Iranian sheep and non-cerebral cysts from Iranian goats have $100 \%$ genetic identity (15). The goal of the recent study was to description a rare case of non-cerebral coenurus cyst on the myocard of a ewe heart and to characterize its macroscopic and microscopic features.

\section{CASE REPORT}

\section{Collection and Examination of Sheep Carcasses}

On May 14, 2018, during the routine post mortem inspection from carcasses and offal of slaughtered ewes in Isfahan (Iran), an ovine heart was discovered with a firm nodule in the left ventricle on palpation. At necropsy, a liquid containing cyst $(1 \times 1$ $\mathrm{cm}$ ) was recognized on the myocardial wall. The cyst had thick fibrotic capsule in outer surface and a thin inner layer containing few white scolices cluster. White clusters contained scolices that adhered to the inner transparent layer, like white beads (Figure 1). There were not internal or external daughter cysts in depth observation. The invaginated scolices were dispersed to the inner surface (Figure 2). Ethics Committee approval was received for this study from the Animal Ethics Committee of Agricultural Research, Education and Extension Organization (AREEO) $(2016 / 48445 / 1)$.

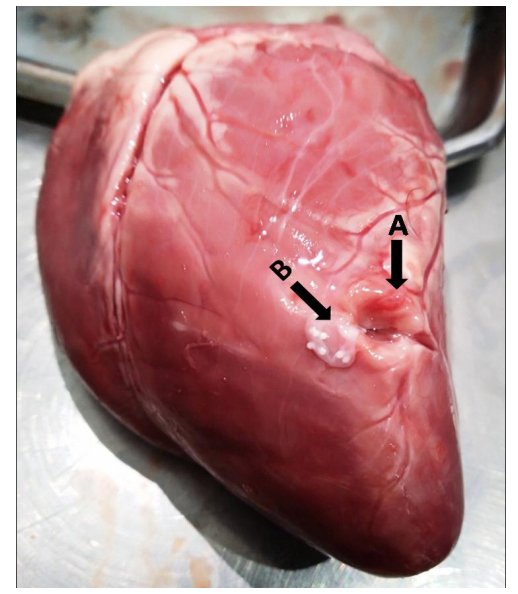

Figure 1. A) Dilatation of the left ventricle with pressure atrophy of the surrounding myocardial tissue

B) A small cyst measuring $1 \times 1 \times 1 \mathrm{~cm}$ in diameter was connected and left a cavity in the myocardial tissue

\section{Microscopical Examination}

Microscopically each scolex had one rostellum, with a double crown of 32 taeniid hooks and four suckers (Figure 3). The hooks and the hooklets were approximately 150 and $137 \mu \mathrm{m}$, respectively (Figure 4). Typical taeniid hooks were characteristic of those of coenurus (Figure 5), the cyst were identified as non-cerebral coenurus, the intermediate stage of T. multiceps.

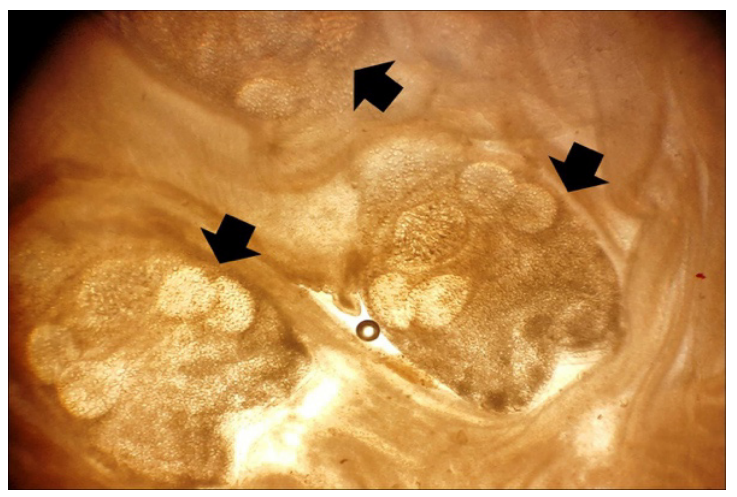

Figure 2. Fresh isolated coenurus cyst with protoscolices (arrow)

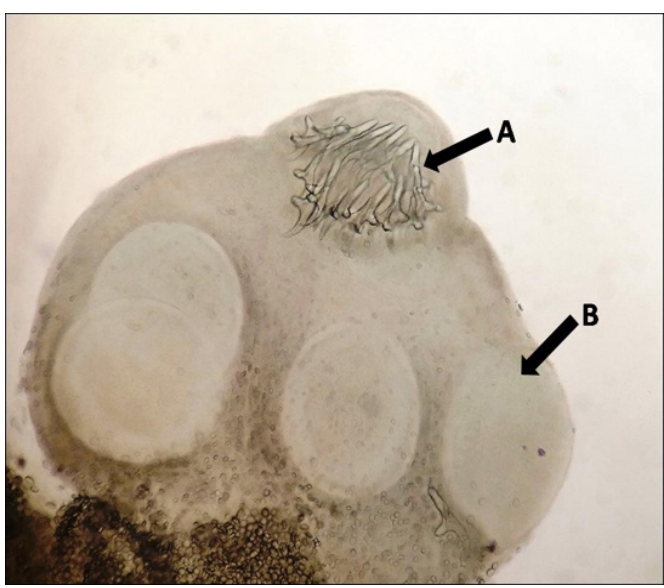

Figure 3. Fresh unstained typical Taenia multiceps protoscolex A) rosellar hooks, B) sucker

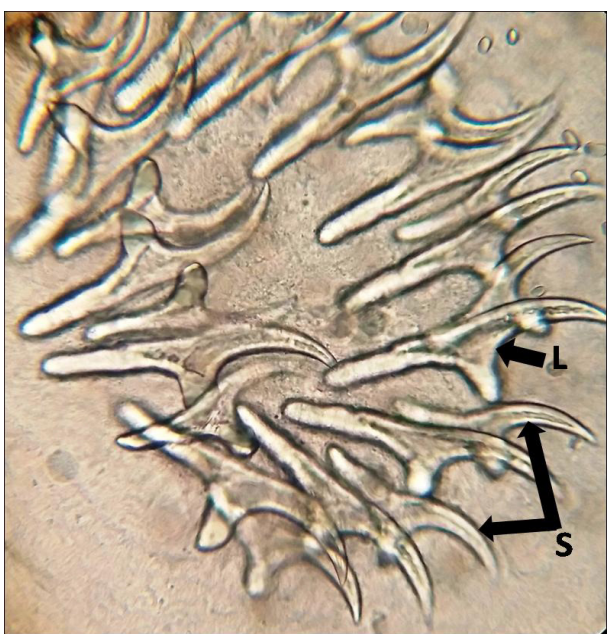

Figure 4. Large (L) and small (S) rostellar hooks (lateral view) 


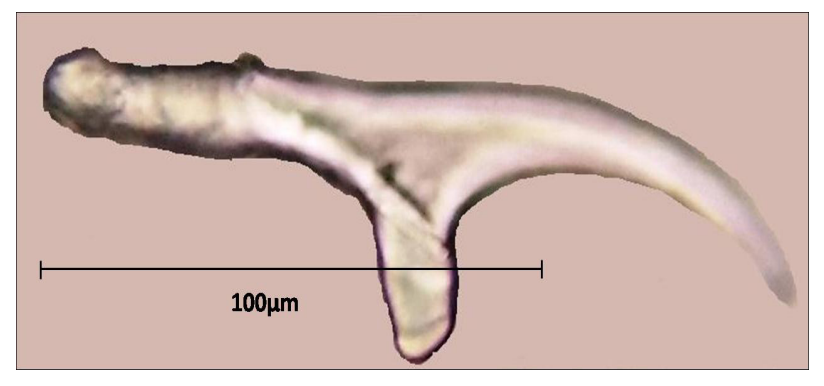

Figure 5. The size estimination of large rostellar hook

\section{DISCUSSION}

Every year several carcasses are locally confiscated due to cerebral and non-cerebral coenurosis by meat hygiene inspectors in the world (4). The disease can cause economic losses for the sheep and goat industry in Middle East, where cases are relatively frequent (1).

Sheep are the ordinary hosts of T. multiceps larval stage. Localised cysts are often detected in the central nervous system such as brain and spinal cord of infected animals (16). In Asia, cerebral coenurosis has been reported in sheep in India, Jordan, Iraq, Turkey and Iran with a wide range of infection from $2.9 \%$ to $28.5 \%$ (1). The non-cerebral form of coenurosis is more commonly found in goats and is less frequent in sheep (4). In the most Asian and African countries, unlike Europian or American countries, there are several descriptions of non-cerebral coenurus cysts in muscles, kidneys, liver and omentum in slaughtered goats $(17,18)$. The incidence of the disease in the goat is between $0.09 \%$ and $18.65 \%$ at different areas of Iran $(1,14)$. Despite non-cerebral coenurosis in sheep is rare it has been reported in muscles, diaphragm, abdomen, omentum and subcutaneous tissue $(1,17)$.

It has been shown that most non-cerebral cysts in sheep are found intramuscularly (1). According to available information the present study is the first report of non-cerebral coenurus on the myocard.

In this study, the sheep examined had the upper than 3 years old. The coenurosis has rarely been reported in sheep over than 3 years old. Previous studies show that coenurosis in sheep is an age-related disease, and it is common in young animals aged 6 to 18 months (19). Tavassoli et al. (2011) (18) also reported that the highest prevalence of coenurosis in sheep was in animals aged 6 to 24 months (20).

In this study, the size of the cyst was $1 \mathrm{~cm}^{3}$ with eight scolices. Schuster et al. (2010) (20) reported that non-cerebral cysts size change between 1 and $40 \mathrm{~cm}^{3}$ and the number of scolices per cyst change between 46 and 474 (21). In other study in Iran the cerebral cyst sizes were between 1 and $4.5 \mathrm{~cm}$ (20). In this study the size of the cyst was similar to later finding but the number of scolices per cyst was less than the ones reported in other studies. In this case, the number of hooks was 32 and the large hooks were approximately $150 \mu \mathrm{m}$ and the small hooks were $137 \mu \mathrm{m}$ in length. According to the reports, the number of hooks in each scolex varies from 28 to $32(1,4)$. Oryan et al. (2014) (11) reported that the length of the hooks was 128-169 $\mu \mathrm{m}$ and 106-122 $\mu \mathrm{m}$ for large and small hooks, respectively (1). Morphologically, the hooks examined in our results were in consistent with previous reports.

\section{CONCLUSION}

The present study described a unique case of coenurosis in heart of a sheep. Though non-cerebral coenurosis has been reported in various muscles, this is the first document of heart coenurosis. Effective control measures in endemic regions include: public notification of the epidemiology of the coenurosis, hygienic discarding of offal, deworming of dogs by regular taenicide treatment and control of stray dog population.

\section{* Ethics}

Ethics Committee Approval: Ethics Committee approval was received for this study from the Animal Ethics Committee of Agricultural Research, Education and Extension Organization (AREEO) (2016/48445/1).

Informed Consent: Patient was not informed.

Financial Disclosure: This work was supported partially by the Isfahan Agricultural and Natural Resources Research and Education Center, AREEO, Isfahan, Iran.

\section{Acknowledgements}

The authors would like to thank all the staff working in Falavarjan abattoir for useful assistance.

\section{REFERENCES}

1. Abera S, Wubit T, Nejash A. Cerebral Coenurosis in Small Ruminants: A Review. J Anim Sci Adv 2016;6:1595-608.

2. Akbari M, Moazeni M, Oryan A, Sharifiyazdi H, Amrabadi O. Experimental cerebral and non-cerebral coenurosis in goats: A comparative study on the morphological and molecular characteristics of the parasite. Vet Parasitol 2015;211:201-7.

3. Amrabadi O, Oryan A, Moazeni M, Sharifiyazdi H, Akbari M. Comparison of cerebral and non-cerebral coenurosis by genetic markers of glycolytic enzyme (enolase) and mitochondrial sequences in sheep and goats. Vet Parasitol 2015;214:333-6.

4. Benkovskij V. Taenia coenurus in sheep. Vestnik obshcestvennoj Veterinarii 1899;12:549 (in Russian).

5. Christodoulopoulos G, Kassab A, Theodoropoulos G. Occurrence of noncerebral coenurosis in sheep. J Helminthol 2013;87:125-7.

6. Gaiger SH. Coenurus serialis found in two goats in India. J Trop Vet Sci 1907;2:316-21.

7. Hall MC. A new and economically important tapeworm, Multiceps gaigeri from the dog. J Am Vet Med Assoc 1916;50:214-23.

8. Haridy M, Sakai H, El-Nahass el-S, El-Morsey A, Anwar S, Yanai T. Coenurus cerebralis cysts in the left lateral cerebral ventricle of a ewe. J Vet Med Sci 2013;75:1643-6.

9. Kheirandish R, Sami M, Azizi S, Mirzaei M. Prevalence, predilection sites and pathological findings of Taenia multiceps coenuri in slaughtered goats from south-east Iran. Onderstepoort J Vet Res 2012;79:1-5.

10. Oge H, Oge S, Gonenc B, Ozbakis G, Asti C. Coenurosis in the lumbar region of a goat: a case report. Vet Med 2012;57:308-13.

11. Oryan A, Akbari M, Moazeni M, Amrabadi OR. Review Paper Cerebral and non-cerebral coenurosis in small ruminants. Trop biomed 2014;31:1-6.

12. Popov NP. Cenuroz myshc ovec. Ucennye Zapisi Kazanskogo Gosudarstvennogo Zooveterinarnogo Instituta 1937;47:353-63.

13. Rostami S, Beech RN, Salavati R, Baneshi MR, Kamyabi H, Harandi MF. Morphometric Analysis of Larval Rostellar Hooks in Taenia multiceps of 
Sheep in Iran and Its Association with Mitochondrial Gene Variability. Iran J Parasitol 2013;8:579-85.

14. Schuster RK, Sivakumar S, Wieckowsky T. Non-cerebral coenurosis in goats. Parasitol Res 2010;107:721-6.

15. Schuster RK, Sivakumar S, Wieckowsky T, Reiczigel J. Abattoir survey on extra-cerebral coenurosis in goats. Helminthologia 2015;52:303-9.

16. Smith, MC \& Sherman DM. 2009. Goat medicine, 2nd edn. Ames, IA, Wiley-Blackwell, Oxford, p.85-256.

17. Soulsby EJI. 1982. Helminthes, Arthropods and Protozoa of Domesticated Animals, 7th ed. p.809.
18. Tavassoli M, Malekifard F, Soleimanzadeh A, Tajik H. Prevalence of Coenurus cerebralis in sheep in Northwest of Iran. Vet Res Forum 2011;2:274-76.

19. Upadhayay, AK. (Ed.), 2005. Text book of preventive medicine. First edition, Int. book distributing company (Publ. Div.). p.452-54.

20. Varcasia A, Jia WZ, Yan HB, Manunta ML, Pipia AP, Garippa G, et al. Molecular characterization of subcutaneous and muscular coenurosis of goats in United Arab Emirates. Vet Parasitol. 2012;190:604-7.

21. Verster A. A toxonomic revision of the genus Taenia Linnaeus, 1758 S. str. Onderstepoort J Vet Res 1969;36:3-58. 